\title{
Chlorogenic Acid Attenuated Inflammatory Response in Kidney Disease with Ischemic Reperfusion Injury
}

\author{
Ali Multazam ${ }^{1 *}$, Sri Lestari Sulistyo Rini ${ }^{2}$ and Nur Arfian ${ }^{3}$ \\ ${ }^{I}$ Department of Physiotherapy, Faculty of Health Science, University of Muhammadiyah Malang, \\ Indonesia \\ Jl. Bendungan Sutami 188A, Kota Malang, Jawa Timur, 65145 \\ ${ }^{2}$ Departement of Physiology, Faculty of Medicine, Universitas Gadjah Mada, Indonesia \\ Jl. Farmako Sekip Utara, Sinduadi, Mlati, Kabupaten Sleman, Daerah Istimewa Yogyakarta, 55281 \\ ${ }^{3}$ Departemen of Anatomy, Faculty of Medicine, Universitas Gadjah Mada, Indonesia \\ Jl. Farmako Sekip Utara, Sinduadi, Mlati, Kabupaten Sleman, Daerah Istimewa Yogyakarta, 55281 \\ *Corresponding author: azzamphysio@yahoo.com
}

\begin{abstract}
Background: Ischemia reperfusion injury $(I / R)$ at kidney has known as the primary cause of AKI and the most seeing through it. Chlorogenic acid (chlorogenic acid/CGA) is one of the most common polyphenols in the human diet. Chlorogenic acid has an antioxidant effect, antiapoptosis, antiinflammation, antifobrosis. Objective: To investigate the anti-inflammatory effect of chlorogenic acid on the kidneys with I/R injury. Method: Twenty male mice (3 months-old). The animals were divided into 4 groups, Ischemia reperfusion (IR, $n=5$ ), I/R injury given CGA dose $3.5 \mathrm{mg} / \mathrm{kg} / \mathrm{BW}$ (IRCGA1, $n=5), I / R$ injury given CGA dose of $7 \mathrm{mg} / \mathrm{kg} / \mathrm{BW}$ (IRCGA2, $n=5)$, and I/R injury given $C G A$ dose $14 \mathrm{mg} / \mathrm{kg} / \mathrm{BW}$ (IRCGA3, $n=5)$. The CGA was given intraperitoneally injection for 3 days. At the end of the examination, serum creatinine and leukocytes levels were taken from retroorbital venous blood. The data were analyzed by one-way ANOVA and Kruskal-Wallis statistic test $(p<0.05)$. Result: The IRCGA3 group showed an increase of creatinin serum and leukocytes level compared to the IR group ( $p<0.05)$. Conclusion: Chlorogenic acid is known antioxidant and anti-inflammatory can inhibit the inflammatory response.
\end{abstract}

Keywords: Acute Kidney Injury, Chlorogenic Acid, Inflammation, Leukocyte

\section{INTRODUCTION}

Kidney failure is a major public health problem worldwide. Kidney failure is the development of acute kidney injury (Bonventre \& Yang, 2011) AKI incidence is increasing both in developed and developing countries (William et al, 1997; Yun, et al, 2012). In Indonesia, the incidence rate of AKI reached $17 \%$ of 15,980 patients undergoing hemodialysis. Ischemia reperfusion injury (I/R) at kidney has known as the primary cause of AKI and the most seeing through it (Domitrovich, et al, 2014). The extension phase of the reperfusion ischemic injury is characterized by two major events: continuous hypoxia and an inflammatory response caused by vascular endothelial cell damage. During this phase the cell continues to suffer injury and death, both necrosis and apoptosis (Rabb et al, 1997)

Chlorogenic acid (chlorogenic acid/CGA) is one of the most common polyphenols in the human diet. Chlorogenic acid is an active substance found in many fruits and vegetables, including apples, blueberries, tea, coffee, potatoes. Green coffee is the main source of chlorogenic acid in nature (Farah, et al, 2008). Chlorogenic acid has an antioxidant effect, 
antiapoptosis (Ji, et al, 2013), antiinflammation (Chauhan, et al, 2013), antifobrosis (Shi, et al, 2009).

\section{METHOD}

The subject used were 20 Swiss male mice aged three months and 30-40 grams of mass. The mice were housed in Laboratory of Anatomy Faculty of Medicine Universitas Gadjah Mada at standard room temperature and 12-h light/dark cycle. Animals were divided into 4 groups: IR ( $\mathrm{I} / \mathrm{R}$ injury, $\mathrm{n}=5$ ), IRCGA1 ( $/ \mathrm{R}$ injury + chlorogenic acid dose 3,5 $\mathrm{mg} / \mathrm{kg} / \mathrm{BW}, \mathrm{n}=5$ ), IRCGA2 (I/R injury + chlorogenic acid dose $7 \mathrm{mg} / \mathrm{kg} / \mathrm{BW}, \mathrm{n}=5$ ), and IRCGA3 (I/R injury + chlorogenic acid dose $14 \mathrm{mg} / \mathrm{kg} / \mathrm{BW}, \mathrm{n}=5$ ).

Mice were anesthetized using a solution penthobarbital $1: 10$ (dose $0.1 \mathrm{mg} / \mathrm{BW}$ ) by intraperitoneal injection. IR group performed the procedure in the form of an incision in the anterior abdomen of mice, at the midline, followed by exploration of the renal hilum and clamping of the renal pediculus right and left for 30 minutes. Chlorogenic acid was administered intra-peritoneal in the IRCGA1, IRCGA2, and IRCGA3 groups at day 1 and day 2 extension phases. Blood was obtained from retroorbital vein for creatinin and leukocytes measurement at day 3. All samples were brought to Clinical Pathology Laboratories Faculty of Medicine UGM for measurement.

\section{RESULT AND DISCUSSION}

I/R injury induced in mice caused an imbalance between the vasoconstrictor mediator and vasodilation in the blood vessels. Under conditions of ischemia, there will be oxygen and nutritional supply disruptions both locally and general, as well as disruption of waste substances from the kidneys (LeDorze, et al, 2009). Microvascular will experience a vasoconstrictive response and decreased vasodilatory response as well as increased endothelial damage and smooth vascular muscle cells, leukocyte-endothelial adhesion, and inflammation (Bonventre \& Yang, 2011). Initiation phase occurs when a decrease in renal blood flow results in an ATP depletion. Ischemia induces temporary or permanent changes in structure and function with disruption of cell f-actin (Siegel, et al, 1994; Thadani, et al, 1996; Ashworth \& Molitoris, 1999). The extension phase which is a continuation of the initiation phase is characterized by advanced hypoxia and an inflammatory response. This inflammatory response is a major characteristic of the extension phase (Sutton, et al, 2002).

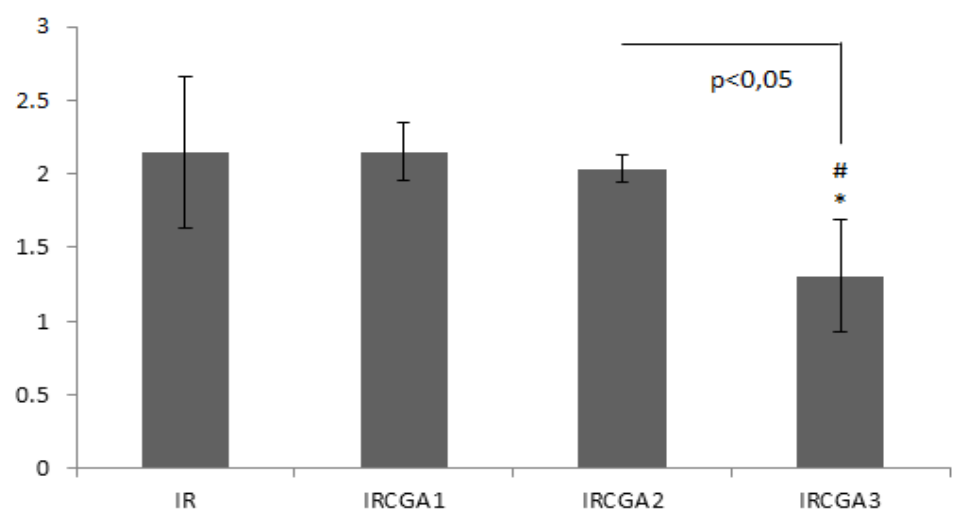

Figure 1 Diagram of mean value of serum creatinine level. Description: IR (ischemic reperfusion), IRCGA1 (ischemic reperfusion + chlorogenic acid dose 3,5 mg/kg/BW), IRCGA2 (ischemic reperfusion + chlorogenic acid dose $7 \mathrm{mg} / \mathrm{kg} / \mathrm{BW}$ ), IRCGA3 (ischemic reperfusion + Chlorogenic acid dose $14 \mathrm{mg} / \mathrm{kg} / \mathrm{BW}) . *=\mathrm{P}<0.05$ vs IR, \#=p<0,05 vs IRCGA1. 
The results of the creatinine serum level at IR group and IR+chlorogenic acid group increased serum creatinine level. Significant reductions in creatinine levels in the IRCGA3 chlorogenic acid group were compared to the IR group ( $p<0.05)$ (Fig.1). Indicators of loss of renal function can be detected with elevated BUN and serum creatinine (Wei \& Dong, 2012). Creatinine is a marker of filtration because it has the properties of the unbound protein, free filtered and not metabolized in the kidneys. The decline of GFR in renal disease will cause the creatinine filtration to decrease so that serum creatinine will increase (Perrone, et al, 1992). Increased creatinine levels in the IR model reached a maximum after $24 \mathrm{~h}$ of reperfusion and decreased to basal level after 7 days due to the recovery of renal function.

Chlorogenic acid inhibits the inflammatory response and increases antioxidants. The inflammatory response is inhibited through TLR4 also by decreasing the activity of NF- $\kappa \mathrm{B}$ In addition, inhibition of inflammatory responses resulted from decreased expression of tumor necrosis factor $\alpha(\mathrm{TNF} \alpha)$ and cyclooxygenase-2 (COX-2). This attenuated cell death programs in the tubules. The activity in kidney can remain functionally optimal. BUN and creatinine levels are suppressed (Francischetti, et al, 2010).

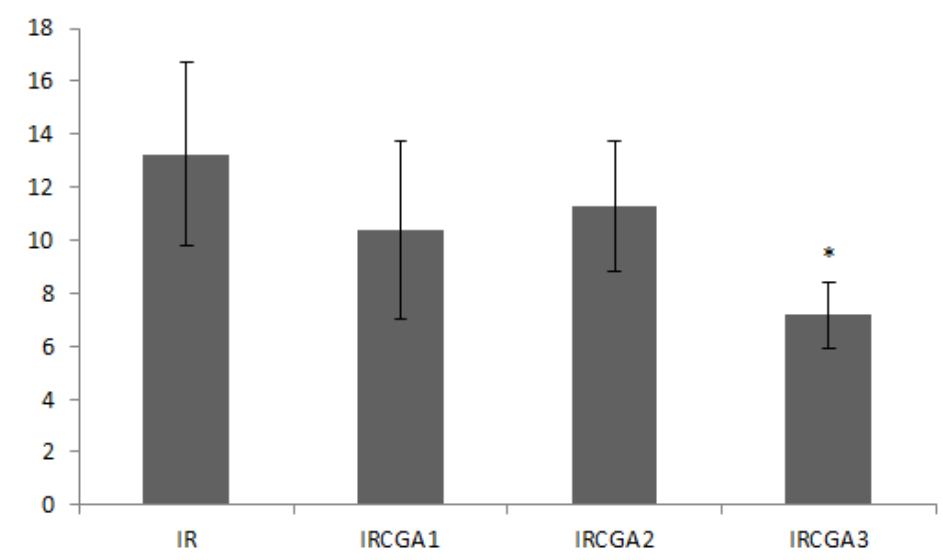

Figure 2 Diagram of mean value of leukocytes level. Description: IR (ischemic reperfusion), IRCGA1 (ischemic reperfusion + chlorogenic acid dose $3,5 \mathrm{mg} / \mathrm{kg} / \mathrm{BW}$ ), IRCGA2 (ischemic reperfusion + chlorogenic acid dose $7 \mathrm{mg} / \mathrm{kg} / \mathrm{BW}$ ), IRCGA3 (ischemic reperfusion + Chlorogenic acid dose $14 \mathrm{mg} / \mathrm{kg} / \mathrm{BW}){ }^{*}=\mathrm{P}<0.05$ vs IR.

The examination, the number of leukocytes from the IR group and the chlorogenic acid group increased the number of leukocytes. A significant decrease of leukocytes level in the IRCGA3 chlorogenic acid group compared with the IR group ( $p<0.05)$ (Fig.2). Ischemiareperfusion stimulated a systemic inflammatory response. Leukocytes have an important role in the inflammatory response. Leukocytes are the main blood cells involved in the inflammatory response, although platelets and red blood cells also participate. Neutrophils are the most important in the pathogenesis of inflammation. They are predominant cells in acute inflammation (Farah, et al, 2008; Bonventre \& Yang, 2011) During ischemia, anaerobic metabolism occurs, with increased lactic and inorganic phosphates and decreased $\mathrm{pH}$, adenosine triphosphate (ATP) and creatine. Recovery of blood flow (reperfusion), which is required for the restoration of cellular function, may aggravate existing lesions in ischemia, causing irreversible damage and cell death. The introduction of molecular oxygen $(\mathrm{O} 2)$ in ischemic tissue produces oxygen-free radicals, greatly damaging cells that can initiate a systemic inflammatory systemic inflammatory reaction. This then stimulates the increase in neutrophils as an acute inflammatory response [Ali et al, 2007]. Chlorogenic acid is known to have a role in inhibiting pro-inflammatory cytokines including TNF $\alpha$. The inflammatory response with leukocytes has attenuated. 


\section{CONCLUSION}

Ischemic reperfusion injury caused increased leukocytes as an inflammatory response which then modulates cell death programs. This caused kidney function will be disrupted so that creatinine will increase. Chlorogenic acid can be an alternative therapy. Chlorogenic acid is known antioxidant and anti-inflammatory can inhibit the inflammatory response by inhibiting the production of pro-inflammatory cytokines.

\section{REFERENCES}

Ali, T., Khan, I., Simpson, W., Prescott, G., Townend, J., \& Smith, W. (2007). Incidence and outcomes in acute kidney injury: a comprehensive population-based study. J Am Soc Nephrol.18:1292-1298

Ashworth, S.L., \& Molitoris, B.A. (1999). Pathophysiology and functional significance of apical membrane disruption during ischemia. Curr Opin Nephrol Hypertens. 8:449458.

Bonventre, J.V. \& Yang, L. (2011). Cellular pathophysiology of ischemic acute kidney injury. J Clin Invest. 121:4210-4221.

Chauhan, P.S., Satti, N.K., Sharma, V.K., Dutt, P., Suri, K.A., \& Bani, S. (2011). Amelioration of inflammatory responses by Chlorogenic acid via suppression of proinflammatory mediators. J. Applied Pharmaceutical Sci. 1: 67-75

Domitrovic R, Cvijanovic O, Susnic V, \& Katalinic N. (2014). Renoprotective mechanisms of chlorogenic acid in cisplatin-induced kidney injury. $J$ Tox. 324:98-107.

Francischetti, Ieda., Moreno, José Bitu., Scholz, Martin., Yoshida, \& W Bonetti. (2010). Leukocytes and the inflammatory response in ischemia-reperfusion injury. Rev Bras Cir Cardiovasc. 25: 575-584

Farah, A., Monteiro, M., Donangelo, C. M., Lafay, S. (2008). Chlorogenic Acids from Green Coffee Extract are Highly Bioavailable in Humans. J Nutr. 138: 2309-2315

Ji, L., Jiang, P., Lu, B., Sheng, Y., Wang, X., \& Wang, Z. (2013). Chlorogenic acid, a dietary polyphenol, protects acetaminophen-induced liver injury and its mechanism. $J$ Nutr Biochem. 24: 1911-1919.

Le Dorze, M., Legrand, M., Payen, D., \& Ince, C. (2009). The role of the microcirculation in acute kidney injury. Curr Opin Crit Care. 15: 503-508

Mehta, R.L., Pascual, M. T., Saroko, S., Savage, B. R., Himmelfarb, J., \& Ikizler, T.A. (2004). Spectrum of acute renal failure in the intensive care unit: the PICARD experience. Kidney Int. 66: 1613-1621

Murugan, R., \& Kellum, J.A. (2011). Acute kidney injury: what's the prognosis?. Nat Rev Nephrol.7: 209-217

Perkumpulan Nefrologi Indonesia (PERNEFRI), (2012). $5^{\text {th }}$ Report of Indonesian Renal Registry. PERNEFRI. Jakarta: 1-40

Perrone, R.D., Madias, N.E., \& Levet, A.S. (1992). Serum creatinine as an index of renal function: new insight into old concepts. Clin. Chem. 38: 1933-1953.

Rabb, H., O’Meara, Y.M., Maderna, P., Coleman, P., \& Brady, H.R. (1997). Leukocytes, cell adhesion molecules and ischemic acute renal failure. Kidney Int. 51:1463-1468.

Shi, H., Dong, L., Bai, Y., Zhao, J., Zhang, Y., Zang, L. (2009). Chlorogenic acid against carbon tetrachloride-induced liver fibrosis in rats. Eur J Pharmacol. 623: 119-124

Siegel, N.J., Devarajan, P., VanWhy, S. (1994). Renal cell injury: Metabolic and structural alterations. Pediatr Res. 36:129-136.

Sutton TA, Fisher CJ, Molitoris BA. (2002). Microvascular endothelial injury and dysfunction during ischemic acute renal failure. Kidney Int. 62:1539-1549. 
Thadhani, R., Pascual, M., Bonventre, J.V. (1996). Acute renal failure. N Engl J Med. 334: 1448-1460.

Uchino, S., Kellum, J. A., Bellomo, R., Doig, G.S., Morimatsu, H., \& Morgera, S., (2005). Acute renal failure in critically ill patients: a multinational, multicenter study. JAMA. 294: 813-818

William, P., Lopez, W., Britt, D., Chan, C., Ezrin, A., Hottendorf, R. (1997). Characterization of renal ischemia-reperfusion injury in rats. J Pharmacol Toxicol Methods. 37: 1-7.

Wei, Q. \& Dong, Z. 2012. Mouse model of ischemic acute ktes and idney injury: technical notes and tricks. Am J Physiol Reanl Physiol. 303:1487-1494.

Yun, N., Kang, J.W., Lee. (2012). Protective effects of chlorogenic acid against ischemia/reperfusion injury in rat liver: molecular evidence of its antioxidant and antiinflammatory properties. J Nutr Biochem. 23:1249 - 1255 